\title{
The Migrant Children In Urban Space And Economy： A Study Of Itanagar, The Capital Township Of Arunachal Pradesh, India
}

\author{
Dr. Nandini.C.Singh, \\ Associate professor Dept. of geography Rajiv Gandhi University, Rono Hills, Itanagar Arunachal Pradesh, pin \\ 791112 India
}

\begin{abstract}
In India, urban development in hilly and tribal regions of the country is of recent origin. Most of these regions with subsistence mode of production and egalitarian social setup, being in the geographical and economic periphery of the country have remained stagnated till recently. The NorthEastern part of India is one such example where the process of urbanization began late and started growing mainly in the post independence era, more as an after effect of the plan and policies of the government. Consequently the associated features of getting urban started manifesting its impact in the form of migration, Poverty and its associated features which are now obvious in most towns located or emerging in the tribal areas. Witnessing a transformation of the earlier tribal social ethos towards modernization, these societies are thereby breaking the age old traditions, getting reshaped as result of being suddenly exposed to the new culture and the waves of change in them. The impact is mostly felt in the catchment rural areas by the migrant laborers a majority of whom are children and the young people who constitute a sizable section of the tribal society in the form of residential domestic help and even commercial workers. Families of these teenagers migrant are forced to use their children as a source of economic sustenance by sending them out to the expanding towns and cities where there is high demand for children aged 14 and above, particularly among the Neo-rich and the nuclear families mostly as residential domestic help. This paper examines the mobility and space given to these rural migrant children who become the bread earners for their families and contribute to the urban economy through their unrecognized labour.
\end{abstract}

Key words; egalitarian, ethos, stagnated, subsistence, transformation, waves of change

\section{Introduction}

The process of urbanization is broadly seen as reorganization of space in response to changes in the economy [1]. Urban development in any region is therefore understood in terms of increasing complexity of the economy with associated changes such as increased surplus generation greater division of labour and occupational shifts of population.[2]] Urban development in hilly and tribal regions in Indian context, remaining as they are in the geographical and economic periphery of the country has not followed the same course as that of the developed peasant economics.[3] Most areas with subsistence economics have fewer urban centers, compared to those with more developed (complex) economies. At the same time it is interesting to note that there are glaring instances of high rates of urbanization and growth of urban centers when are expanding continuously with in regions which have a perseverance of subsistence economics. Urban development in north eastern part of India is one such example where urbanization process is gathering fast momentum, particularly among the tribal population who have remained isolated both physically and socially due to the locational and cultural heterogeneity that while on the one hand make a rich traditional heritage, but denotes a deep difference from the general or so called non tribal people on the other. Naturally then the process of urbanization in these areas needs to be understood in a broader frame work where the whole system appears to have been superimposed more than that of a inbuilt growth process.

Consequently the major impact of such urbanization are migration (particularly unskilled migrants from the rural areas) poverty and its associated features, which are now obvious in most of towns located or emerging in these tribal areas. The change is most prominently visible in the social structure, experiencing change in the form of breaking of age old traditions and reshaping of the old egalitarian social ethos, ushering in the more complex profit oriented capitalist mode like class formation and privatization of resources which were almost unknown to these societies.

urbanization process in the entire North East is of recent origin, a process that started more comprehensively particularly with the emphasis on the tribal development policies and consequently the different states of North East exhibit different developmental stages depending upon their location i.e. physical, social and economic aspects. Arunachal Pradesh popularly known as NEFA in the recent past is one such example that came to focus only recently and therefore stands at the lowest level in the developmental index in comparison to the national average. 


\section{The Land and the People}

Arunachal Pradesh the land of rising sun, located in the eastern most corner of India represents one of the most unique picturesque landscapes for an observer both in the context of physical diversity and cultural heterogeneity. Tucked in between $26^{\circ} 28^{\prime}$ to $29^{\circ} 31^{\prime}$ north latitude and $91^{\circ} 31^{\prime}$ to $97^{\circ} 30^{\prime}$ east longitude, fig. 1 its topography represents the diversity ranging from the rolling grass lands to the snow capped mountains. Keeping pace with the wide physical heterogeneity, the people of the land reflect a huge cultural diversity. Arunachal Pradesh is the home of Twenty-six major and many minor tribes who are integrated in a mosaic of diversity and unity, which remained almost unknown to the rest of country due to long drawn isolation from the main land. These tribes have continued to sustain and exist within the varied landscape in isolation from the main land in terms of socio cultural mingling, and have consequently continued to perpetuate within their cultural practices, traditions for generations. The present state of Arunachal Pradesh till 1954 was known as the North East Frontier Tract and from 1954-1972 as the North East Frontier Agency. Till 1965, the administrative responsibility of the territory rested with the Ministry of External Affairs, Government of India. After 1965, its responsibility was taken over by the Ministry of Home Affairs, Government of India.[4] It attended the status of Union Territory in 1972 and the status of a full fledged state in 1987.

During all this processes the continuity of traditional practices and stagnation had left a lasting impression on the state's social, economic and cultural landscape which stared to face the changes with the coming up of inroads in to these areas. [5]

Thus within such a frame it appears natural that the concept of urbanization in Arunachal Pradesh is a more recent phenomenon. Virtually both that is the process of urbanization and exposure to the urban way of life began in the post independent era when new inroads were made in these areas to bring at par the long isolated (Both physically and socio-economically areas, along with the main stream of the country. Consequently the urban way of life in the perspective of shift in economy exposed the tribal groups to a totally new concept of reorganization of space both in the spatial and social context along with the multiple and complex nature of the economy. But interestingly though new, these tribal groups started to accept and change largely in to new ways of life, particularly in the context of money economy resulting in to a situation which can be broadly stated as -

a)Rapid migration to the areas called towns which were virtually imposed structural areas particularly for administrative purpose and were basically unplanned construction and growth lacking proper facilities to manage and handle such sudden and large influx of people.

b) Pressure on the system for white collar jobs as people who migrated were reluctant to continue in their earlier occupation, i.e. mainly agriculture.

c) Formation of a urban class which unlike the joint family system and kinship relations in the rural area started to become more nuclear mainly due to economic and space factor and more orientation toward ownership of private property.

d) Class formation-creating a gap in the social spectrum there by breaking the traditional egalitarian social order, and all these led to a

e) new concept of paid labour as most the nuclear families did not have the kinship support like that of a village system,

Resultant immigration of the paid labour from the nearby areas and belonging to other social and linguistic system began. (As employing ones own kinship members is not socially acceptable in the tribal social order and hence the demand of the helping hand trough a system of wage had to be fulfilled from outside their social structure as an extra hand as helper or a domestic help to look after the daily chores as well as for caring of the children since most of these families consists of parents and children

Even if the wife is not working keeping a maid or helper is counted as a status symbol. Such kind of a scenario has resulted in the ushering in of large-scale migrants mostly children and youth from the neighboring state of Assam and even as far of state as West Bengal and Tripura to cater to the need. Since most of these helpers are kept at home or in other words are provided accommodation under the same roof, the age group choice is usually between 11 yrs to 19 yrs with strong preference of mostly female dominating over the male, the reason may be the adaptability and security factors involved.

Within this emerging picture understanding of the urbanised and their urban space as well as the population dynamics generates a number of quarries which are but pertinent in the context of future planning and development, like

1) How far the process of urbanization have got imbedded in the tribal way of life and in what way.

2) What is the degree of demand of the paid labour /helper in these societies and how they are met with?

3) Place of origin and role of the migrant groups in the township both in the economic social and demographic set up of the state .and.

4) Whether such kind of social change will lead to identity crisis and larger instability prevalent in the other states of the North East 


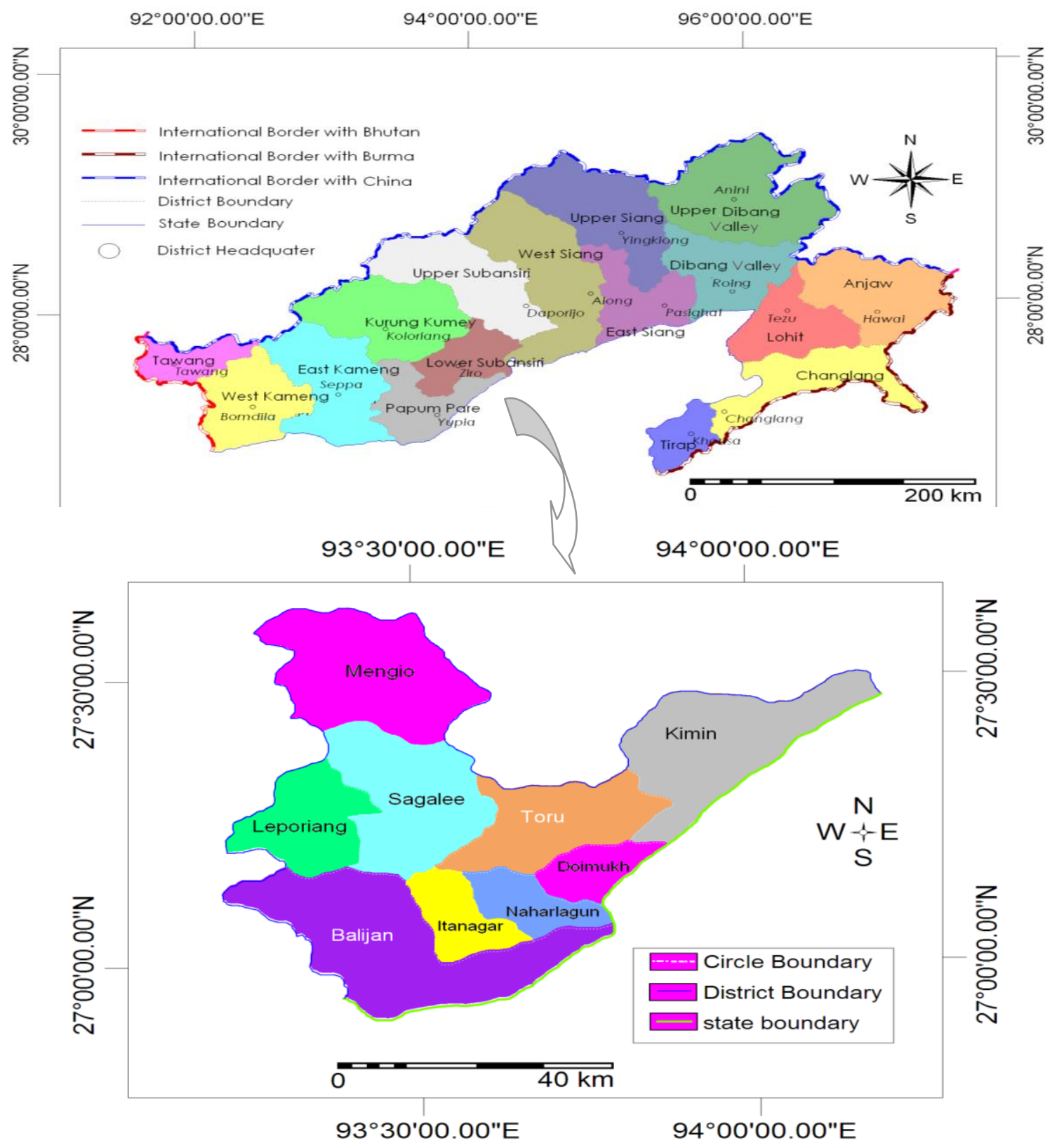

Fig.1.Location of the Study area

The present paper attempts to understand these trends and patterns within the urban context, particularly focusing on the migration of the labour force to the capital town of Itanagar. As stated earlier a neo rich class has been emerging within the tribal social system forming the class divisions, some thing that was almost unknown to these societies prior to the introduction of the money economy ..

In order to answer these quarries some basic parameters like the age-sex, place of origin, educational status, nature of work performed, wage/salary drawn and the categories of employees who employ and accommodate these helpers/maids have been adopted to understand and sketch the emerging trends.

\section{Methodology:}

The study is based upon the collection of primary data as no such secondary data /record was available in any form. The data for the study was collected through random sampling method of a sample size forming $10 \%$ of the total population which roughly stands at 1,98563 (2001census) in the twin town ship of Itanagar and Naharlagun. Survey was conducted by the use of scheduled questioners at Itanagar, the capital 
complex and surroundings and mainly focused and selected the urbanized sections engaged in, administrative education and political and commercial activities.

The field work was undertaken in the month of May 2010 across the different economic class group with an objective to figure out the nature of labour force employed by them, the place of migration/origin of these labours and the role of these migrants in the family as well as in the social set up.

The data obtained provided a number of interesting features that brought out a picture indicating change in almost all aspects of the so far practiced and prevalent tribal social order.

Age Groups-To begin with an attempt has been made to understand the nature of demand for the helpers or the general preference of employing. From the data collected and analyzed TABLE 1,Fig 2 it appeared that a strong preference of young children is more prevalent than the youths. This may be reasoned as less space required for accommodation, less wage and more authoritative control. What ever may be the case in the employment of residential helpers the younger age groups is found to be strongly dominant as evident from the table.

In the survey questionnaire an age gap of 4 years was taken to incorporate the surveyed categories. It becomes evident that the initial migrant group starts from 10 -to 14 years and is forms a sizable section in the category of domestic help. As stated earlier a strong preference of female domestic help prevails over the male, consequently the percentage of female migrants in this group strongly dominates. The relationship virtually shows and inverse trend with increase in age group mainly because after 19 years the female helper is either sent back to the place of origin or they get married and move out of the house. TABLE 2, Fig.3, One interesting factor that emerges from the table is that a sizable percentage of the migrants come from the ST or scheduled tribe section popularly known as Adivasis who are the Tea garden labourers whose for fathers were brought in by the colonial rulers to work in the gardens or for other menial jobs.

The next group that forms a sizable section are in the general category that is neither SC, ST or OBC and belong to different linguistic group.

A considerable section of SCs are also prevalent in almost all the age groups of the migrants. The conspicuous absence of $\mathrm{OBC}$ in the lower age category and low presence in the higher age category indicates less prominence of these caste groups in these areas.

Table -1

Age - sex and categories of migrant children/teenagers e in the study area ( in percentage).

\begin{tabular}{|l|l|l|l|l|l|l|l|}
\hline Sl. & Age groups & Male & Female & Categories & General \\
\cline { 4 - 7 } No. & & & & SC & ST & OBC & \\
\hline 1. & $\mathbf{1 0 - 1 4}$ & $\mathbf{3 0}$ & $\mathbf{7 0}$ & $\mathbf{1 0}$ & $\mathbf{4 0}$ & - & $\mathbf{5 0}$ \\
\hline $\mathbf{2 .}$ & $\mathbf{1 5 - 1 9}$ & $\mathbf{2 0}$ & $\mathbf{8 0}$ & $\mathbf{1 5}$ & $\mathbf{4 5}$ & - & $\mathbf{4 0}$ \\
\hline 3. & $\mathbf{2 0 - 2 4}$ & $\mathbf{5 5}$ & $\mathbf{4 5}$ & $\mathbf{1 2}$ & $\mathbf{3 0}$ & $\mathbf{1 0}$ & $\mathbf{4 8}$ \\
\hline 4. & $<24$ & $\mathbf{7 0}$ & $\mathbf{3 0}$ & $\mathbf{1 5}$ & $\mathbf{2 3}$ & $\mathbf{1 5}$ & $\mathbf{5 7}$ \\
\hline
\end{tabular}

Source based on house hold \& market survey of the study area.

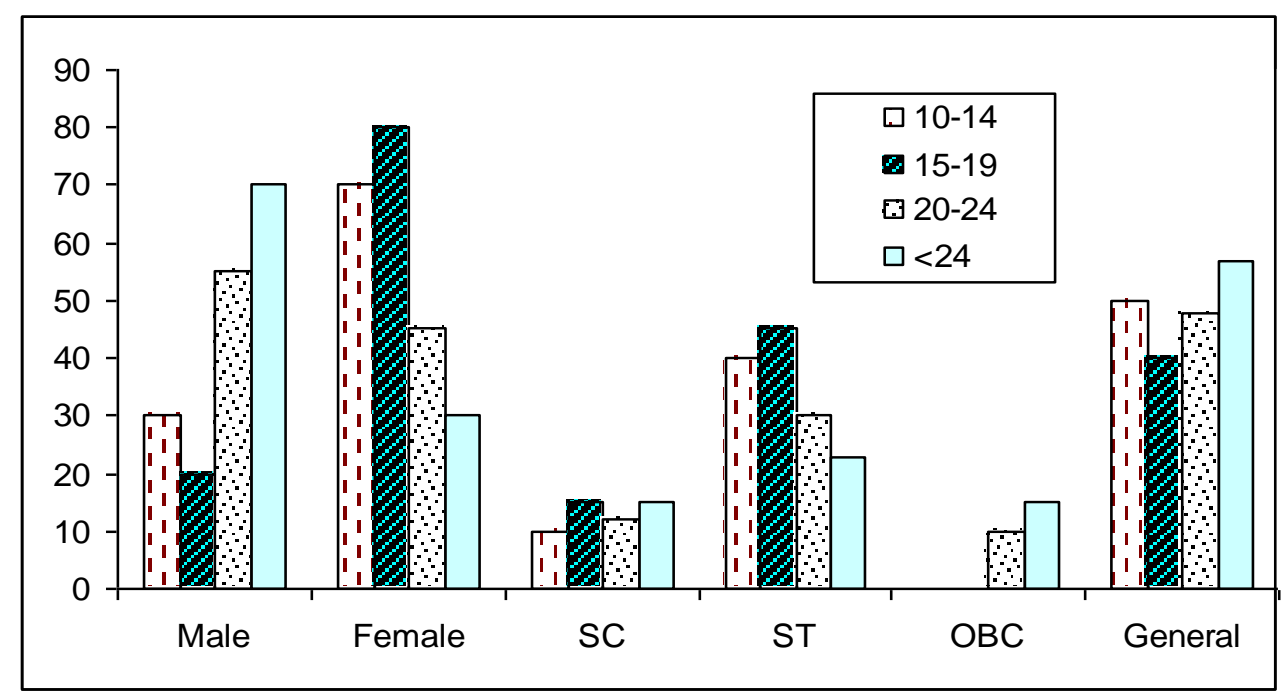

Fig 2 Age - sex and categories of migrant children/teenagers e in the study area 
Place of Migration -TABLE-2 and Fig-3 indicates that in almost in all age group the neighboring state of Assam strongly predominates. This can be understood from the geographical nearness on the one hand and a strong push factor in the form of poverty that virtually compels these families to send their children to become bread earners for them. Mostly girls are sent out, as they are preferred in the place of employment Further social taboo like education is not required for girl's ads to this compulsive migration for the sake of the family.

(When surveyed it was found that most of these children belonged to families who were either tea garden labourers or farmers or petty vendors, whose monthly income did not exceed sometime Rs 1200/- and were having large family size.).

Next to Assam it is the state of West Bengal particularly Cooch-Bihar which caters to the labour supply. The reason for these migrations comes as a result of contact or in continuation to earlier migration. Mostly some known person from the area brings in other migrant to cater to the demand of either their employees or known people. In the last category, migrants from Bihar, Uttar Pradesh and Nepal also constitute a mentionable proportion. These migrations usually take place on the basis of networking of the earlier migrants in the town.

Table -2 Showing the age group and place of migration (in percentage)

\begin{tabular}{|c|c|c|c|c|c|}
\hline \multirow{2}{*}{$\begin{array}{l}\text { Sl. } \\
\text { No. }\end{array}$} & \multirow[t]{2}{*}{ Age groups } & \multicolumn{4}{|c|}{ Place of migration } \\
\hline & & Assam & West Bengal & Tripura & Any othel \\
\hline 1. & $10-14$ & 70 & 15 & 10 & 5 \\
\hline 2. & $15-19$ & 65 & 15 & 12 & 8 \\
\hline 3. & $20-24$ & 57 & 28 & 8 & 7 \\
\hline 4. & $24>$ & 60 & 22 & 11 & 9 \\
\hline
\end{tabular}

(Any other includes migrants from Nepal Bihar\& UP.)

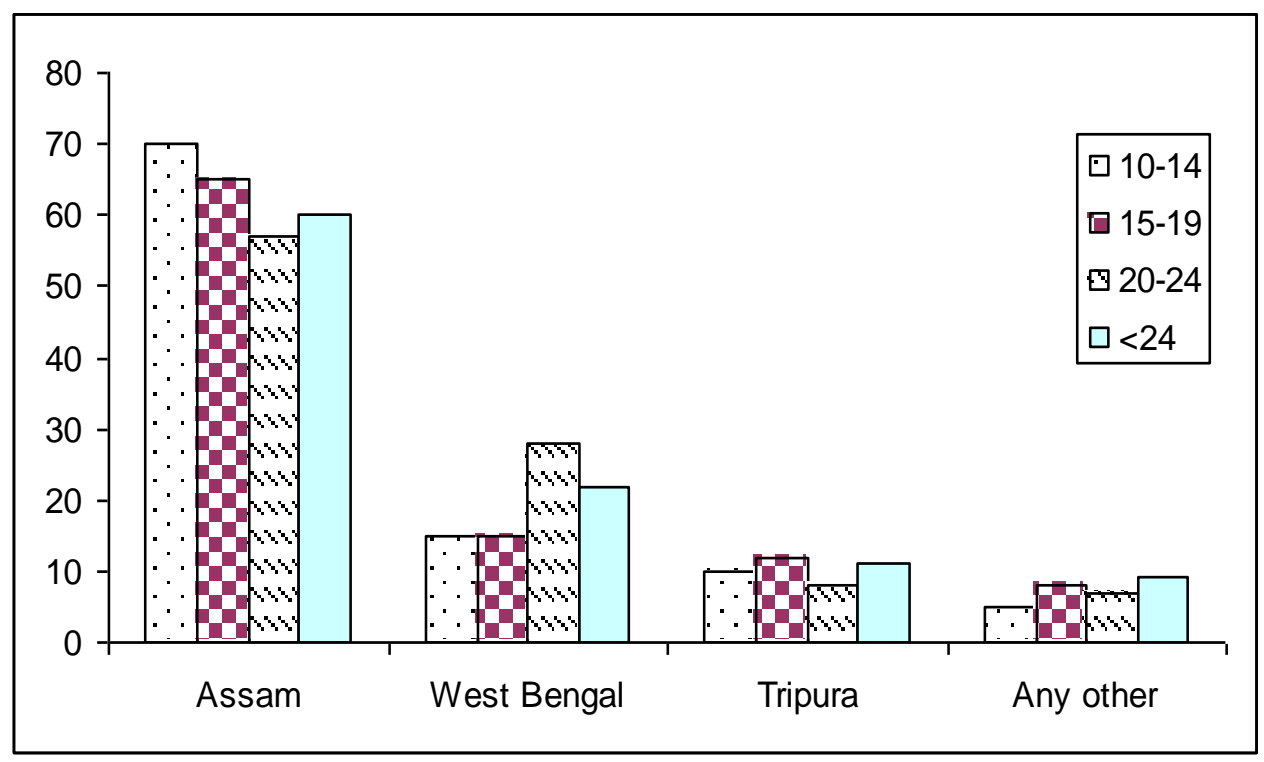

Fig. 3 The age group and place of migration

Duration of Stay-In the survey it was found that a sizeable migrant children who come to be employed as domestic help are mostly accommodated in the house TABLES-3\&4 and Fig.4(a) \&(b) and 5. The employer usually provides for food, lodging and all other day to day requirements besides a sum agreed upon while employing. As evident from the above two tables $3 \& 4$ that in the lower age group that is $10-14$ years almost $95 \%$ are residential while only $5 \%$ comprise of non residential categories. These may be due to the fact that a number of local resident children who prefer to work from their own place of stay. Also the duration and nature of work as well as the skill ability largely varies from age group to age group. As evident from table 4, the percentage of house maids in the age group to 10-14 mostly dominate the stay duration of two to four years, while the next group dominates 4 years and more than four year categories.

In both cases the share of percentage appears to be inversely related to the age group. Justifying the fact that most of the migrant children/ teenager youths tend to choose a different occupation after a certain age, or may prefer to return back to their own place of origin. This condition becomes more applicable for the girls as they are married off with in 16 to 20 years of age. 
Marriage by elopement is also found to be quite prevalent mostly among the age group of 15 onwards .

Table -3

Showing nature of stay and employment categories (in percentage)

\begin{tabular}{|l|l|l|l|l|l|l|l|}
\hline $\begin{array}{l}\text { Sl. } \\
\text { No. }\end{array}$ & Age groups & $\begin{array}{l}\text { Nature } \\
\text { of stay } \\
\text { in house }\end{array}$ & $\begin{array}{l}\text { Stay part } \\
\text { time }\end{array}$ & $\begin{array}{l}\text { Any other } \\
\text { employed like } \\
\text { shop/hotels }\end{array}$ & Skilled & unskilled & Total \\
\hline 1. & $10-14$ & 95 & - & 5 & Nil & 100 & 100 \\
\hline 2. & $15-19$ & 68 & 20 & 12 & 5 & 95 & 100 \\
\hline 3. & $20-24$ & 31 & 40 & 39 & 28 & 62 & 100 \\
\hline 4. & $24>$ & 20 & 60 & 20 & 62 & 48 & 100 \\
\hline
\end{tabular}

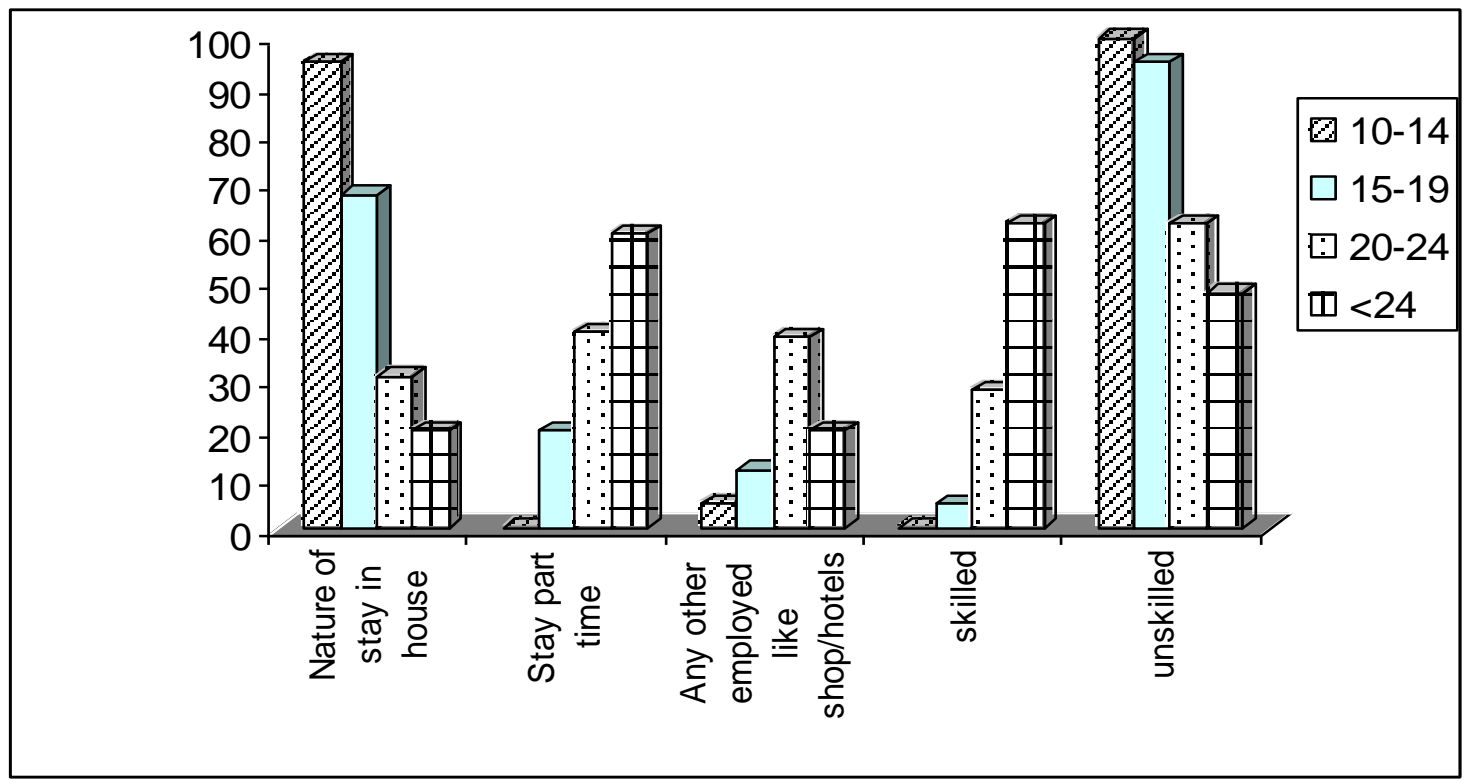

Fig-4 (a)\&(b) Showing nature of stay, work and wage categories

Table -4

Showing duration of stay, nature of work and wage categories (in \%)

\begin{tabular}{|l|l|l|l|l|l|l|l|l|l|l|l|}
\hline Sl. & Age & \multicolumn{3}{l|}{ Duration of stay } & \multicolumn{3}{l|}{ Nature of work } & \multicolumn{3}{l|}{ Salary monthly } \\
\cline { 3 - 13 } $\begin{array}{l}\text { No } \\
\text { groups }\end{array}$ & $\begin{array}{l}\text { Last } \\
2 \\
\text { yrs }\end{array}$ & $\begin{array}{l}\text { last } \\
4 \\
\text { yrs }\end{array}$ & $\begin{array}{l}\text { Mor } \\
\text { e } \\
\text { than } \\
4 \text { yrs }\end{array}$ & $\begin{array}{l}\text { Recently } \\
\text { employe } \\
\text { es }\end{array}$ & $\begin{array}{l}\text { Dome } \\
\text { istic } \\
\text { chore } \\
\text { s }\end{array}$ & $\begin{array}{l}\text { Speci } \\
\text { fic } \\
\text { work }\end{array}$ & $\begin{array}{l}\text { Any } \\
\text { other }\end{array}$ & $>500$ & $\begin{array}{l}500- \\
1000\end{array}$ & $<1000$ \\
\hline 1. & $10-14$ & 40 & 37 & 11 & 14 & 100 & - & - & 53 & 42 & 5 \\
\hline 2. & $15-19$ & 26 & 44 & 17 & 13 & 87 & 13 & - & 22 & 62 & 16 \\
\hline 3. & $20-24$ & 14 & 69 & 8 & 9 & 48 & 52 & - & - & 39 & 61 \\
\hline 4. & $<24$ & 17 & 53 & 22 & 8 & 33 & 77 & - & - & 22 & 78 \\
\hline
\end{tabular}




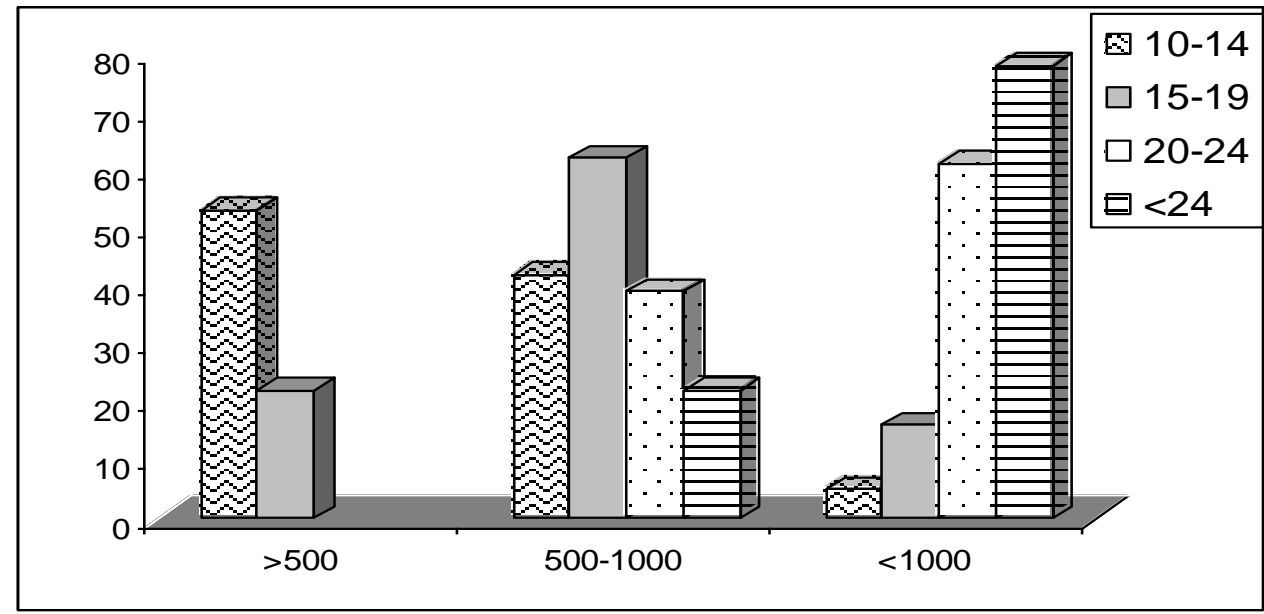

Fig 5 Age Group and income categories

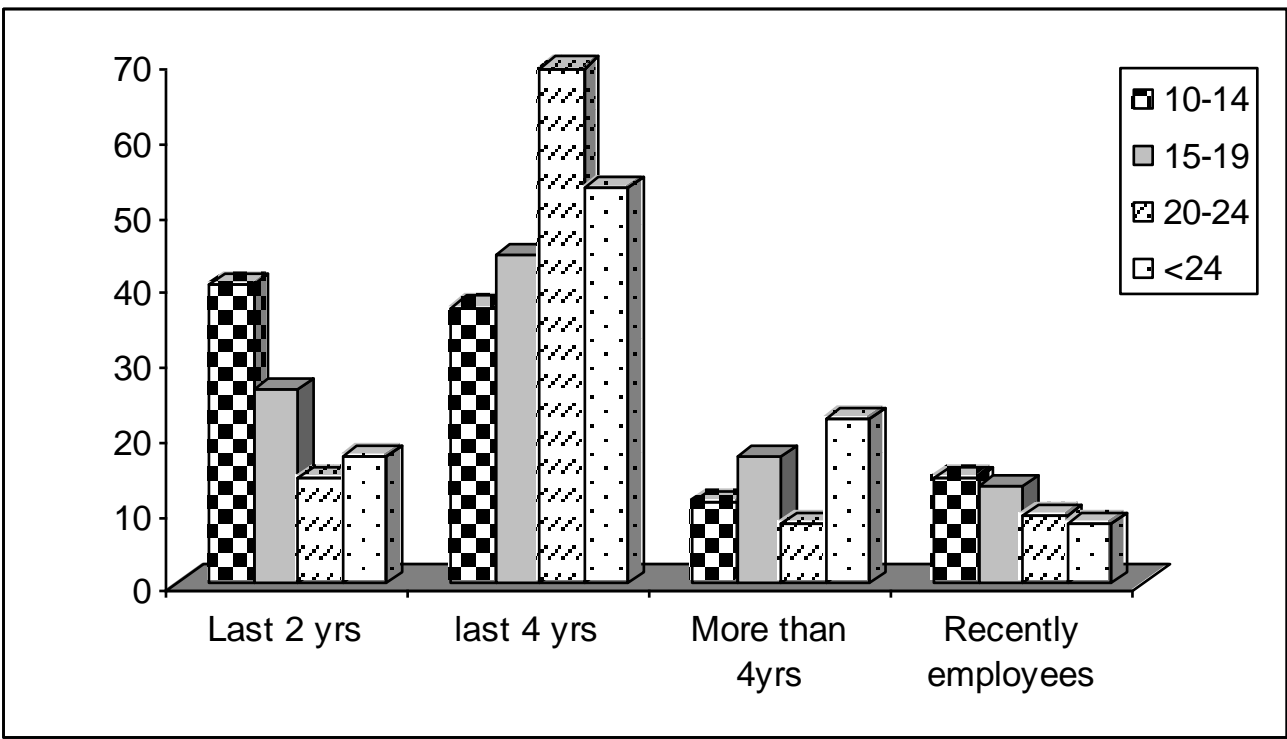

\section{Nature of Work}

\section{Fig 6, Showing Duration of stay}

The nature of work for these migrant children and youth mostly fall under the unskilled category particularly in the lower age group as most of them do domestic help which may include daily chores, looking after the young children and other associate work and though it involves a fulltime engagement it does not qualify for the technical term of skilled.. The trend however changes in the higher age group which indicates multiple employment and different nature of job. Mostly in the age group of 20-24 and above 24 category, the nature of work becomes skilled as by that time a majority of these migrant youth tend to adopt a number of other activities like driving, working in shops, PCOs etc. A good numbers are also employed by their own employers after they attend a certain age and have stayed for a long period or so. (in the process of survey cases have been found where the domestic help had entered as a child and have been with the family for more than 9 or 10 years ,and is now employed either in some job or have their own occupation as vendor or shopkeeper etc.).

\section{Income/Salary}

Interestingly the income or salary components of these migrant children and youth shows a direct relationship, that is lower the age group lower the salary or monthly payment. As evident from the table a large segment of the children helpers/maids usually earn a paltry monthly salary of Rs 500 or below. This changes with the higher age which can be perhaps explained as a general thought pattern that the nature and volume of work would be more and may be more specified and hence their payment categories is also will vary 
accordingly. As children cannot take up the whole responsibility or are not trusted to be given all the house hold chores their monthly payments usually remains low. In comparison, in the higher age group this situation becomes reverse and therefore the payments are usually made in the comparatively higher bracket. Most often for the lower age group the payment of monthly salary is done as advance to the families. This serves as guarantee for the stay of the helper in one hand while lures the families to continue to compel at times the child for staying on even if the working condition is not conducive.. Such kind of one time payments which is cumulative of months and sometimes even years appears big sum on the other hand and enables these families to meet their requirements in one go something which is rare among them mostly existing below the poverty line . One of the important indicators of the compulsive migration is the education level or literacy aspects among the migrants.

Table -5 Education level /literacy levels of the migrant children \& youths.

\begin{tabular}{|l|l|l|l|l|l|}
\hline Age groups & \multicolumn{2}{|l|}{ Levels of education } & $\begin{array}{l}\text { Class XI pass \& } \\
\text { above }\end{array}$ & $\begin{array}{l}\text { Any other like } \\
\text { vocational etc. }\end{array}$ \\
\hline & Illiterate & $\begin{array}{l}\text { Up to class } \\
\text { V }\end{array}$ & $\begin{array}{l}\text { Upto class } \\
\text { VIII }\end{array}$ & & \\
\hline $10-14$ & 83 & 17 & - & - & - \\
\hline $15-19$ & 52 & 33 & 12 & - & 3 \\
\hline $20-24$ & 23 & 21 & 16 & 14 & 16 \\
\hline $24>$ & 18 & 33 & 27 & 10 & 12 \\
\hline
\end{tabular}

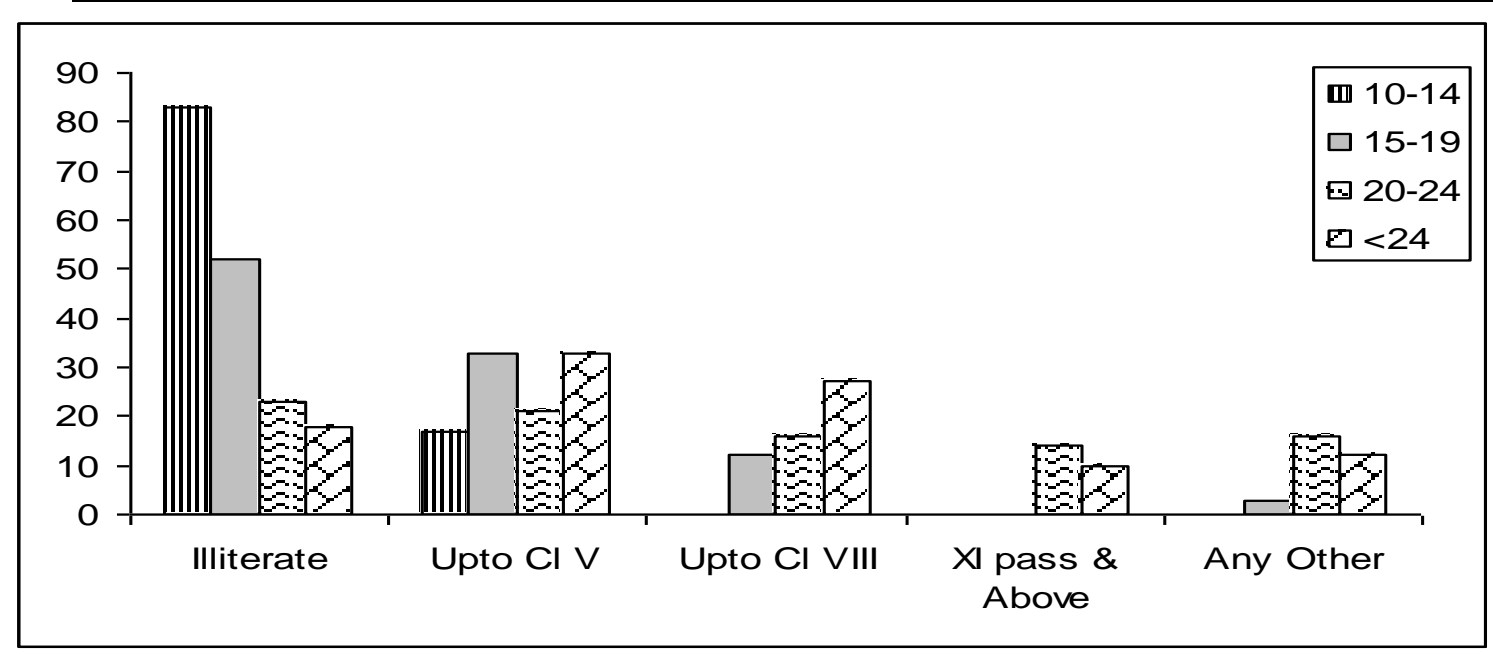

Fig.7 Showing TheEducation level /literacy levels of the migrant children \& youths

\section{Education level /literacy levels of the migrant children \& youths}

The TABLE-5and Fig -6 shows very high degree of prevailing illiteracy particularly in the lower age group among the migrants. This can be explained as acute case of poverty in affordability and compulsion where a very large section i.e. 83\% of the migrant children who come to work as domestic help have never been to school or even have got education otherwise. One of the main reasons of course continues to be the poverty factor; while social values like educating a male child in place of a female also plays its role.

Further the large number of the siblings in the family also forces compulsive choice and very often the female child is left out. As she stays at home the concept of employing her becomes more poignant and is seen as a helping hand to run the family purse. In many cases the school going female child is made to leave her studies, either to look after the younger siblings at home or is sent out for employment in these towns. The percentage share in the table however indicates an inversely related trend, that is higher the age group lower the illiteracy factor.

Thus from the emerging trends is a significant indicator of the fact that a phase of transition is shaping the tribal population of Arunachal Pradesh and the prominence of a new class which is continuously emerging largely adopted in urban way of life, there by deviating from the traditional tribal mode of living. This gets reflected in food, dress, and use of daily consumable items, settlement pattern and the modified cultural continuity.

It is this neo-rich urbanized class who is catering to the ever increasing migration of the young people /helpers particularly in the domestic sector, and is reshaping their own urban place. These families mostly nuclear in type are thereby affecting the dynamics of the new urbanized population. Mostly these families are engaged in tertiary occupations employed in different sectors of jobs across the occupation structure. 
Table -6

Showing the status of employee occupation income(per month) and family size

\begin{tabular}{|l|l|l|l|l|l|l|l|l|}
\hline $\begin{array}{l}\text { Nature of } \\
\text { domestic } \\
\text { help Age } \\
\text { groups }\end{array}$ & \multicolumn{2}{|l|}{ Nature of occupation } & \multicolumn{2}{l|}{ Income groups } & \multicolumn{2}{l|}{ Family size } \\
\hline & $\begin{array}{l}\text { Govt. } \\
\text { Service }\end{array}$ & Private & Business & $\begin{array}{l}20000- \\
400000\end{array}$ & $\begin{array}{l}< \\
40000\end{array}$ & Nuclear & Medium & Joint \\
\hline $10-14$ & 22 & 33 & 35 & 79 & 21 & 48 & 33 & 19 \\
\hline $15-19$ & 46 & 42 & 12 & 68 & 32 & 53 & 38 & 9 \\
\hline $20-24$ & 27 & 58 & 15 & 27 & 73 & - & 46 & 54 \\
\hline $24>$ & 21 & 59 & 30 & 11 & 89 & - & 63 & 37 \\
\hline
\end{tabular}

Source Field Survey

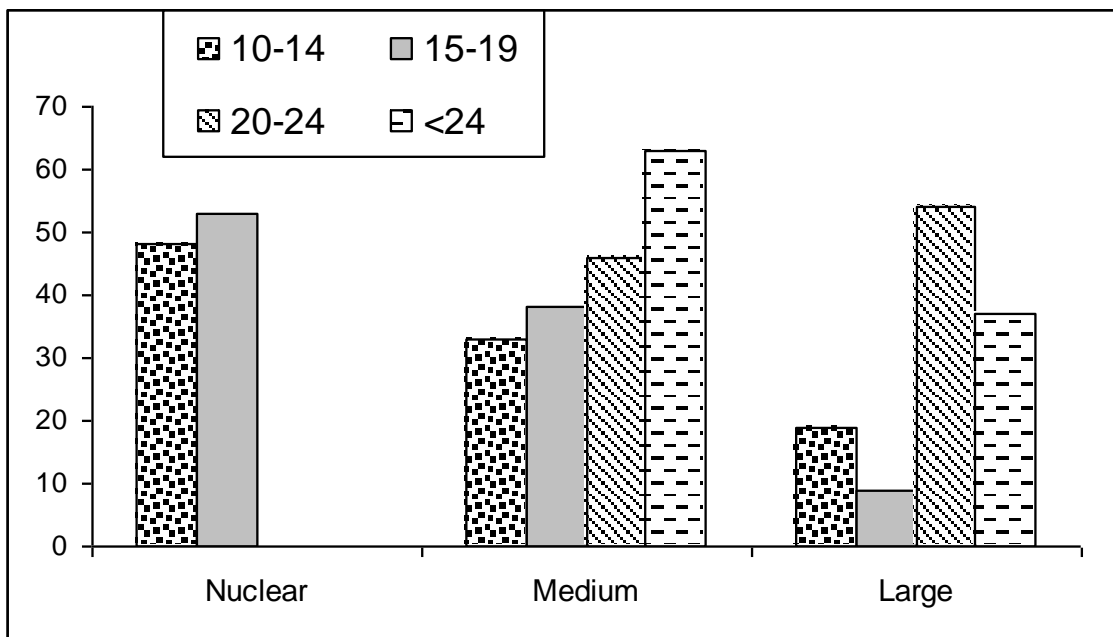

The above TABLE -6 and Fig -7exhibits the nature of job of the employees and the various income categories that employ the domestic as well as part time helpers. It becomes clear from the above data that the larger section of the lower age group are employed by those who are engaged in private jobs followed by the families having business as occupation. The reason may be the long hours of staying out due to job requirements, socializing patterns etc. in case of the govt. servants the engagement for fixed duration can be attributed as one of the main cause for the need of domestic help.

Interestingly the income category of 20,000-40,000 /per month show maximum percentage of employing domestic helper of lower age group which shows a lower trend in the higher income category for the lower age groups. This can be explained as the requirement of more specified and skilled helping hand in these houses depending upon the lifestyle etc. which sets necessary conditions /situation for employment of helpers who are in higher age groups and better skilled for example. Drivers or cook etc.

Thus from all the above information's the trend that emerges show two very clear aspects.

1. Formation of a neo-rich modern urban class in the tribal social order leading to a total reshaping of the traditional mode of existence creating a new state of demand and dependence on paid mode of service than kinship help and ties.

2. A large scale mobility of the children and youth from the neighboring states who are filling in these gaps leading to a cross cultural assimilation by means of their language interactions on one hand and by serving as network link for further migration on the other.

The paper therefore throws light on some basic thrust and trends that can be broadly framed as

A sizeable sections of the tribal population who belong to the middle and upper middle class have started to depend largely on the paid labour or help in most cases the maid, and now have little tie with the kinship network for any physical help and their day to day living.

Mostly these helpers are dominated by the female migrants belonging to 10-19 age group who are called 'Bhontis' in the common parlance migrate from the neighboring state of Assam to cater to need mainly in the townships of Itanagar, Naharlagun and also the nearby areas.

The reasons of these migrations are abject poverty condition in their place of origin, social taboos and economic affordability on one hand and the ever growing demand of paid helpers in these townships on the other. 
Most of these migrants after becoming part of the household get used to the urban ways and often prefer to remain back in the township either by means of getting married or by trying to get in to some petty business on contractual jobs.

Such a trend which is becoming prominent feature of the township is leading to a change in the age sex ratio when the total population is taken in to consideration and may lead to more differential status and its associated impact in the near future particularly in the social and cultural context..

\section{Conclusion}

For a dispassionate observer it become very clear that there is a prominent shift in the tribal social order of Arunachal as aftermath of the impact of modernity and the changes in the neighboring areas which are bringing in ripples of effect that are getting expressed in the form of existence in everyday living patterns. This is more dominantly and prominently felt in the urban areas or can be said under the urbanization effect which is continuously increasing.

These changes while bringing in progress and development in these areas in social cultural and economic scenario to be at par with its counterpart in the country is also experiencing a shift and transition in the traditional values customs and practices as well.

The impact of such changes are felt more by the neighboring rural area particularly among the women and children who are lured to the prospects of better life and cash money in these townships in the process of catering to the ever growing need of domestic or unskilled helper with minimal wage, the migrant youths \& children lose their child hood, suffer a sense of insecurity and also run the risk of sexual harassment and hostile working conditions as well.

These youths and children however remain compelled to continue and exists even in most adverse situations as they turn in to the role of bread earners of their families back home and are burdened with a deep sense of responsibility of dependency of their younger siblings.

In the long run the urban space carve out by these migrant do not defer much from the abject poverty condition of their place of origin as most of them continue to be illiterate and unskilled and thereby joining in the large scale unemployed and partially employed sections with the condition of no job security or prospects, as most of these youths end up in contractual jobs with low payments and whims of the employer.

As migrants their identity often remains in question and sometime compels them to take-up violence and social crime as a means for existence. The basic issue that emerges therefore questions as to where do these children or migrant teenagers stand? What are the possibilities is it possible and viable to stop these changes or the resultant impact. Is it viable to provide a better living condition in the place of origin of these migrants so that they are not compelled or forced to migrate out so early to cater to these kinds of employments

What is future prospect of such transitions? All these needs to be argued not only within the ivory towers of conference venues and discussion in closed chamber meeting places, but in the practical sense of planning and implementation where by urbanisation would become a way of life and not a compelled transition, something that needs to be implemented particularly in the developing countries like India. This becomes more imperative because it is these countries which will contribute to the urbanisation process in the next few years and the trend of which will be shaped up by the young and mobile migrants in the time to come If planned and implemented properly only then perhaps achieving a better social space would become viable where even in transition the pangs and pain of bending and crumbling particularly of the young and vulnerable sections under the impact of such changes will not be felt so deeply.

\section{References}

[1] Soja, Edward, The Reassertion of Space in Critical Social Theory (1989) Verso, London.

[2] Mcgee, T.G. and Bells, G., The Urbanisation Process In The Third World (1979) Macmillan, London

[3] Barpujari, H. K., Problems of Hill Tribes North East Frontier(1998), NERC Shillong

[4] Choudhury.S Gazet6er of India 1980, Gazettier report Arunachal Pradesh

[5] Barpujari.H.K.,The American Missionaries and North-East India 1986,Easstern Publications ,Guwahati 